\title{
The Effect of Service Quality and Servicescape Towards Customer Satisfaction, Starbucks Coffee, Jakarta
}

\author{
Andhalia Liza Marie \\ Sekolah Tinggi Pariwisata Trisakti \\ andhalia_toelle@yahoo.com
}

\begin{abstract}
This study aims to determine the effect of Service Quality and Servicescape towards Customer Satisfaction Starbukcs Coffee, Jakarta. This type of research is explanatory research with a quantitative approach and using survey methods conducted on 100 customers of Starbucks Coffee, Jakarta. Sampling using nonprobability sampling method with purposive sampling technique. Data processing is done by using multiple linear regression analysis tools. Based on hypothesis testing, the results of the $t$ test show that servicescape and service quality have a significant simultaneous effect on customer satisfaction.
\end{abstract}

Keywords: Service quality, Servicescape, Customer satisfaction. 


\section{A. Introduction}

In line with the development of the era, urban communities are currently experiencing lifestyle changes. One manifestation of today's modern lifestyle is the habit of certain community groups who spend time in the coffee shop. Besides being a place to eat and drink, a coffee shop is also used as a place to socialize, where the atmosphere of a coffee shop is supported by a nicely decorated and creative room that makes urbanites interested in going to a coffee shop and having a free wifi area that adds convenience. The existence of a coffee shop is currently felt to be needed by people who have a high level of mobility outside the home with a lifestyle that tends to be dynamic.

The many alternative coffee shops in Jakarta certainly increase the intensity of coffee business competition. The more coffee shops operating in Jakarta, the coffee shop business players are required to have whatever orientation is needed and consumer desires, to create customer satisfaction. In terms of creating competitive advantage in addition to focusing on service and product excellence, coffee shop entrepreneurs must also emphasize the physical environment of the coffee shop itself to create customer satisfaction.

\section{B. Literature Review}

\section{Servicescape}

The process of delivering physical evidence, namely through servicescape. Physical evidence of service characteristics is one of the important elements in service marketing. Yazid (2008: 96) explains that servicescape is a created environment, man-made, physical environment services and tangible forms of communication.

According to Zeithmal and Bitner (2009: 313). Servicescape is defined as: "Physical evidence as the service environment in which the service is delivered and in which the firm and customer interact, and any tangible commodities that facilitate performance or communication of the service" Which means that services are the environment in which services are delivered and where the company and consumers interact, as well as any tangible components that facilitate the appearance or communication of services.

Servicescape according to Fitzsimmons (2011: 154) Servicescape is a physical facility in services designed for guest needs to influence guest behavior and satisfy guests where the design of physical facilities will have a positive impact on guests and employees. Based on the above understanding it can be concluded that Servicescape is a physical display in a place designed in such a way as to attract or influence consumers and employees. 
Lovelock \& Wirtz (2011: 284) which divides the dimensions of servicescape into three parts, namely:

1. Ambient Conditions

The physical quality of the conditions surrounding the individual such as lighting, air temperature, air quality, noise, music and cleanliness are environmental characteristics that are related to the five senses

2. Spatial Layout and Functionality

How to arrange the location, area, equipment and furniture as well as the convenience to be obtained and used by consumers such as location, seating layout and design to facilitate consumer enjoyment.

3. Signs, Symbols, and Artifacts

Signs or decorations that are used to communicate the image to be conveyed to consumers such as company logos, signs or signs and decorations used, to enhance a certain image or mood, which can facilitate consumers to achieve their goals.

\section{Service Quality}

One factor that determines the level of success and quality of the company is the company's ability to provide services to customers. The success of the company in providing quality services to its customers, achieving high market share, and increasing the company's profits are largely determined by the approach used.

The consequences of the service quality approach of a product have an essential essence for the company's strategy to defend themselves and achieve success in the face of competition.

According to (Kotler, 2012), service quality is the totality of the characteristics of goods and services that show their ability to satisfy customer needs, both those that appear clear and hidden. For companies engaged in the service sector, providing quality services to customers is an absolute thing to do if the company wants to achieve success. Service quality can be known by comparing consumers' perceptions of services that they clearly receive or obtain with services that they actually expect or want from the service attributes of a company.

If the service received or perceived (perceived service) as expected, then the quality of service is perceived as good and satisfying. If the service received exceeds consumer expectations, then the quality of service is perceived as very good and quality. Conversely, if the services received are lower than expected, then the quality of service is perceived poorly (Tjiptono, 2014).

Service quality has several dimensions that underlie the formation of service quality. According to Parasuraman there are five dimensions of service quality (SERVQUAL) which underlie the formation of service quality, the five dimensions of service quality are: 
1. Tangible

Tangible, that is, physical evidence of services can be a physical facility of equipment used by physical representation of services.

2. Reliability

Reliability is the ability to provide services that promise appropriately and the ability to be trusted, especially in providing services in a timely manner in accordance with what has been promised without making mistakes.

3. Responsiveness

Responsiviness is the willingness or readiness of employees to provide services needed by consumers.

4. Assurance

Assurance includes knowledge, ability, politeness, and trustworthy nature of personal contacts.

5. Emphaty

Emphaty which includes personal or company contact attitudes to understand needs or difficulties, consumers, good communication, personal attention, and ease of communication or relationships.

\section{Customer satisfaction}

The company's ability to recognize, fulfill and satisfy customer needs well, is a strategy for every company. Customer satisfaction has become a central concept in business discourse. Customer satisfaction will promote to others about the experience provided through the power of mouth and of course a business will have a sustainable period in getting customers Okumu in Putra, Wulan, \& Ingkadijaya, 2018. According to Kotler (2010: 211) suggested the definition of customer satisfaction as follows: "Satisfaction is the level of a felt state person resulting from comparing a producter's perceived performance or outcome in relation to the person's expectations" (Satisfaction is the level at which someone feel from the comparison between the reality produced by the producer in relation to one's expectations). Thus the level of satisfaction is a function of the difference between perceived and perceived expectations. A consumer will experience three levels of satisfaction. If the reality received is lower than expectations, then consumers are not satisfied. If reality matches expectations, consumers are satisfied. If reality exceeds expectations, consumers are very satisfied, very happy or very happy.

Tjiptono (2012: 349) reveals customer satisfaction is a post-purchase evaluation where the alternatives chosen are at least equal to or exceed customer expectations, while dissatisfaction arises if the results (outcomes) do not meet expectations. If the performance below expectations, the customer does not feel satisfied and vice versa if the performance meets expectations, the customer will feel satisfied. 
According to Kotler in Tjiptono (2014), there are four methods to measure consumer satisfaction, consist of:

1) Complaint and Suggestion System

Every customer-oriented company needs to provide the widest opportunity for customers to submit their suggestions, opinions and complaints. Information provided by customers will be very useful to improve existing shortcomings.

2) Customer Satisfaction Survey

Through surveys, the Company will receive responses and feedback directly from customers and at the same time provide a sign that the company is paying attention to its customers. Measurement of customer satisfaction through this method can be done by sharing ways, namely:

- Directly Reported Satisfaction

Measurements are carried out directly through questions on the following scale: Very dissatisfied, dissatisfied, negative, satisfied, very satisfied.

- Derived Dissatisfaction

The questions asked about the two main things, namely: the amount of customer expectations for certain attributes and the amount of performance they feel.

- Problem Analysis

Customers who are respondents are asked to disclose two main things, namely: The problems they face are related to company offers and suggestions to companies to make improvements to the problem.

- Importance-performance Analysis

This method was used by M Artila and James in their article published in the January 1977 journal of marketing entitled "Importance Performance Analysis". In this technique respondents are asked to vote for various elements of the offer based on the importance of each element. In addition, respondents were also asked to rank how well the company's performance in each element or attribute.

3) Ghost Shopping

This method is done by getting a ghost shopper as a potential customer of a competing company product to convey the weaknesses and strengths of the company's products and competitors' products.

4) Lost Customer Analysis

The customer analysis that is switched is aimed at the company contacting customers who have stopped buying or switching to other companies in order to understand why this happened and in order to be able to take further improvement or improvement policies. 


\section{Previous research}

Lumentut (2014) the purpose of this study was to determine whether facilities, servicescape and service quality had an effect on consumer satisfaction of McDonald's Manado. The population used amounted to 44,661 consumers of McDonald's Manado in March 2014, and samples were taken 100 respondents using the accidental sampling method. The analysis used is multiple linear regression. The results showed that servicescape facilities and service quality simultaneously and partially had a significant effect on customer satisfaction. Manoppo (2013), the purpose of this study was to determine the effect of service quality and servicescape on satisfaction cons. The research method used is multiple linear regression analysis and hypothesis testing using the $\mathrm{F}$ and t tests. The sample in the study amounted to 70 respondents. The conclusion of the research results is the quality of service and servicescape simultaneously has a significant positive effect on customer satisfaction visitors to Hotel Gran Puri Manado.

Wijayanigratri (2015), the purpose of this study was to find out whether facilities, locations and services have an effect on customer satisfaction Bank Mega Syariah Walikukun. The sample in the study amounted to 100 customer respondents lending and funding sampling techniques using accidental sampling. The analysis used is multiple linear regression. The results of the study show that facilities, locations and services partially have a significant effect on customer satisfaction at Mega Syariah Bank Walikukun.

The hypothesis in this study is as follows:

H1: Variable service quality significantly influences the level of customer satisfaction.

H2: Servicescape variables significantly influence the level of customer satisfaction.

H3: Service quality and servicescape variables simultaneously have a significant effect on the level of customer satisfaction.

\section{Research methodology}

\section{Types of research}

Based on the background and formulation of the research problem and the theory described, the type of research used is quantitative descriptive research. This is because study wants to provide an overview of data analyzed statistically, systematically, accurately, and clearly. Quantitative analysis is based on the analysis of variables that can be explained in quantity (can be measured) with definite formulas or analyzers. According to According to Sugiyono (2016: 8) interpreting quantitative research as a research method based on the philosophy of positivism, used to examine certain populations or samples, data collection using research instruments, quantitative / statistical data analysis, with the aim of testing predetermined hypotheses . 


\section{Population and Sample Research}

Population is a generalization area consisting of objects or subjects that have certain quantities and characteristics set by researchers (Sugiyono, 2010:117). The population referred to in this study were consumers who had visited Starbucks Coffee, Jakarta.

Determination of the number of samples in this study, the author uses the method according to Slovin. The number of samples is determined using the Slovin formula, which is equal to 100 respondents. The method of selecting this sample is the Non Probability Sampling type of Purposive Sampling, which according to Sugiyono (2016) techniques that do not provide equal opportunities for members of the population to be selected as samples. The samples in this study were:

1. Respondents are at least 17 years old.

2. Respondents who have visited Starbucks Coffee, Jakarta within the last 3 (three) months.

\section{Operational Definition and Research Variables}

1. Service Quality (X1) is the level of excellence expected and control over the level of excellence to meet customer desires (Kotler, 2011: 85). The indicators are:
a. Physical proof (Tangiable)
b. Empathy (Emphaty)
c. Reliability
d. Responsiveness
e. Assurance

2. Servicescape (X2), which is everything that is physically present around consumers during meetings of service transactions that can affect customer perceptions, both internally and externally (Lovelock, 2011: 30). The indicators are:
a. Ambient condition
b. Spatial Planning.
c. Symbols / Artifacts.

3. Consumer satisfaction $(\mathrm{Y})$, that is feeling happy or disappointed someone who appears after comparing between perceptions / impressions of the performance (or results) of a product and expectations (Kotler \& Keller, 2009: 119).

4. The indicators are:
a. Satisfied with service
b. Satisfied with the product
c. Satisfied with the company
d. Satisfied as a whole 


\section{Methodology Analysis Validity test}

Test Validity is used to measure whether a questionnaire is valid or not. A valid or valid instrument has high validity. Conversely, instruments that are less valid means having low validity.

The construct validity in this study was tested using bivariate person (method moment person correlation), the way done by correlating each item with the total value of the total items processed with SPSS version 25, which is said to be valid if the product moment correlation value exceeds or above than 0.30 (Suswanton, 2014).

\section{Reliability Test}

Reliability relates to trust problems, a test can be said to have a high level of trust if the test can provide a fixed confidence outcome. So the understanding of the reliability of the test, related to the problem of the determination of test results or if the results change, the company that occurs can be said to be meaningless. The reliability of an indicator or questionnaire can be seen from the value of Cronbach's Alpha $(\alpha)$, where a construct or indicator is said to be reliable if the value of Cronbach's Alpha $O$ is greater $(>)$ 0.60, then the indicator or questionnaire is reliable, whereas if the value of Cronbach's Alpha $(\alpha)$ smaller $(<) 0.60$ then the indicator or questionnaire is not reliable (Suswanto, 2014).

\section{Multiple Linear Regression Analysis}

Multiple linear regression analysis is an analysis to measure the strength of the relationship between two or more variables, also shows the direction of the relationship between the dependent variable and the independent variable (Ghozali, 2014). The formula for the method of Multiple Regression Analysis is as follows:

$\mathrm{Y}=\mathrm{b} 0+\beta 1 \mathrm{X} 1+\beta 2 \mathrm{X} 2+\beta 3 \mathrm{X} 3+\varepsilon$

Where:

b0 $=$ Constants

$\beta 1=$ Regression coefficient for X1

$\beta 2=$ Regression coefficient for X2

$\varepsilon=$ Standard error

$\mathrm{Y}=$ Customer Satisfaction

$\mathrm{X} 1=$ Servicescape

$\mathrm{X} 2$ = Service Quality 


\section{Research Results}

The results of service quality validity tests show below.

Table 1. Test of Service Quality Validity

\begin{tabular}{cccc}
\hline No. & Result Sig. & $\begin{array}{c}\text { Pearson } \\
\text { Correlation }\end{array}$ & $\begin{array}{c}\text { Result } \\
\text { Description }\end{array}$ \\
\hline P1 & 0,000 & 0,537 & Valid \\
P2 & 0,000 & 0,574 & Valid \\
P3 & 0,000 & 0,636 & Valid \\
P4 & 0,000 & 0,583 & Valid \\
P5 & 0,000 & 0,639 & Valid \\
P6 & 0,000 & 0,537 & Valid \\
P7 & 0,000 & 0,762 & Valid \\
P8 & 0,000 & 0,676 & Valid \\
P9 & 0,000 & 0,596 & Valid \\
P10 & 0,000 & 0,630 & Valid \\
\hline
\end{tabular}

Source: results of 2019 data processing

The table of results of the service quality validity tests above shows that the overall item questions of some service quality indicators meet the validity test can be seen from the results of the Pearson Correlation number $>0.3$

Table 2. Servicescape Validity Test Results

\begin{tabular}{cccc}
\hline No. & Result Sig. & $\begin{array}{c}\text { Pearson } \\
\text { Correlation }\end{array}$ & $\begin{array}{c}\text { Result } \\
\text { Description }\end{array}$ \\
\hline P11 & 0,000 & 0,533 & Valid \\
P12 & 0,000 & 0,570 & Valid \\
P13 & 0,000 & 0,666 & Valid \\
P14 & 0,000 & 0,687 & Valid \\
P15 & 0,000 & 0,706 & Valid \\
P16 & 0,000 & 0,581 & Valid \\
P17 & 0,000 & 0,600 & Valid \\
P18 & 0,000 & 0,566 & Valid \\
P19 & 0,000 & 0,392 & Valid \\
P20 & 0,000 & 0,610 & Valid \\
P21 & 0,000 & 0,677 & Valid \\
P22 & 0,000 & 0,602 & Valid \\
\hline \multicolumn{4}{c}{ Source: results of 2019 data processing }
\end{tabular}

The table of results of the servicescape validity test above shows that the overall item questions of some servicescape indicators meet the validity test can be seen from the results of the Pearson Correlation number $>0.3$. 
Table 3. Customer Satisfaction Test Results

\begin{tabular}{cccc}
\hline No. & Result Sig. & $\begin{array}{c}\text { Pearson } \\
\text { Correlation }\end{array}$ & $\begin{array}{c}\text { Result } \\
\text { Description }\end{array}$ \\
\hline P23 & 0,000 & 0,854 & Valid \\
P24 & 0,000 & 0,831 & Valid \\
P25 & 0,000 & 0,819 & Valid \\
P26 & 0,000 & 0,827 & Valid \\
P27 & 0,000 & 0,822 & Valid \\
\hline
\end{tabular}

Source: results of 2019 data processing

The table of results of the validity test of Customer Satisfaction above shows that the overall item questions of several indicators of Customer Satisfaction meet the validity test can be seen from the results of the Pearson Correlation number $>0.3$.

Table 4. Reliability Test Results

\begin{tabular}{lccc}
\hline \multicolumn{1}{c}{ Variabel } & $\begin{array}{c}\text { Cronbach's } \\
\text { Alpha }\end{array}$ & Critical Value & $\begin{array}{c}\text { Result } \\
\text { Description }\end{array}$ \\
\hline Service Quality & 0,817 & 0,6 & Reliabel \\
Servicescape & 0,835 & 0,6 & Reliabel \\
Customer & 0,887 & 0,6 & Reliabel \\
Satisfaction & & & \\
\hline
\end{tabular}

Source: results of 2019 data processing

The table of reliability test results shows that the entire dependent and independent variables that meet the reliability test can be seen from the Cronbach's Alpha greater than 0.6.

Table 5. Results of Multiple Linear Regression Analysis

\begin{tabular}{|c|c|c|c|c|c|c|c|c|c|c|c|}
\hline \multicolumn{12}{|c|}{ Coefficients $^{\mathrm{a}}$} \\
\hline & & \multicolumn{2}{|c|}{$\begin{array}{c}\text { Unstandardized } \\
\text { Coefficients }\end{array}$} & \multirow{2}{*}{$\begin{array}{c}\begin{array}{c}\text { Standardized } \\
\text { Coefficients }\end{array} \\
\text { Beta }\end{array}$} & \multirow[b]{2}{*}{$t$} & \multirow[b]{2}{*}{ Sig. } & \multicolumn{3}{|c|}{ Correlations } & \multicolumn{2}{|c|}{ Collinearity Statistics } \\
\hline \multicolumn{2}{|c|}{ Model } & B & Std. Error & & & & Zero-order & Partial & Part & Tolerance & $\mathrm{VIF}$ \\
\hline \multirow[t]{3}{*}{1} & (Constant) & .017 & 2.033 & & -009 & .993 & & & & & \\
\hline & servicequality & .348 & .059 & .560 & 5.918 & .000 & .730 & .515 & .397 & .503 & 1.987 \\
\hline & servicecape & .133 & .052 & 241 & 2.548 & .012 & .636 & 250 & .171 & .503 & 1.987 \\
\hline
\end{tabular}




\begin{tabular}{|c|c|c|c|c|c|c|}
\hline \multicolumn{7}{|c|}{ ANOVA $^{\mathrm{a}}$} \\
\hline Model & & $\begin{array}{l}\text { Sum of } \\
\text { Squares }\end{array}$ & df & Mean Square & $\mathrm{F}$ & Sig. \\
\hline \multirow[t]{3}{*}{1} & Regression & 350.935 & 2 & 175.467 & 62.340 &, $000^{b}$ \\
\hline & Residual & 273.025 & 97 & 2.815 & & \\
\hline & Total & 623.960 & 99 & & & \\
\hline
\end{tabular}

Based on the table above, the multiple linear regression equation is obtained as follows:

$\mathrm{Y}=\mathrm{a}+\mathrm{b} 1 \mathrm{x} 1+\mathrm{b} 2 \mathrm{x} 2+\mathrm{e}$

$\mathrm{Y}=0.17+0.348 \mathrm{X} 1+0.133 \mathrm{X} 2$

The above linear regression equation can be explained as follows:

1. Constant 0.17 means that if service quality (X1) and servicescape (X2) the value is zero, the satisfaction value is 0.17 .

2. Service quality (X1) regression coefficient of 0.348 means that if the other independent variables are fixed values and have a $1 \%$ increase, satisfaction will increase by 0.348 .

3. Servicescape variable regression coefficient (X2) is 0.133 which means that if the other independent variables are fixed values and servicescape has increased by $1 \%$, satisfaction $(\mathrm{Y})$ will increase by 0.133 .

Table 6. Determination Coefficient Test Results R2 Model Summary ${ }^{b}$

\begin{tabular}{|l|r|r|r|r|r|}
\hline Model & R & R Square & $\begin{array}{r}\text { Adjusted } \\
\text { R Square }\end{array}$ & $\begin{array}{c}\text { Std. Error of the } \\
\text { Estimate }\end{array}$ & $\begin{array}{c}\text { Durbin- } \\
\text { Watson }\end{array}$ \\
\hline 1 &, $750^{2}$ & .562 & .553 & 1.678 & 1.870 \\
\hline
\end{tabular}

Based on the table above, the $\mathrm{R}$ number is 0.750 . This indicates that there is a strong relationship between service quality and servicescape to satisfaction, while R2 (R Square) is 0.562 or $(56.2 \%)$. This shows that the percentage of the influence of independent variables (service quality and servicescape) on the dependent variable (satisfaction) of $56.2 \%$ or the variation of the independent variables performed in the model (service quality and servicescape) able to explain $56.2 \%$ dependent variation (satisfaction) while the remaining $43.8 \%$ is influenced or explained by other variables not included in this research model. 
Table 7. F Test Results

\begin{tabular}{|l|l|r|r|r|r|r|}
\hline \multirow{2}{*}{ Model } & & $\begin{array}{c}\text { Sum of } \\
\text { Squares }\end{array}$ & df & Mean Square & F & Sig. \\
\hline 1 & Regression & 350.935 & 2 & 175.467 & 62.340 &, $000^{\circ}$ \\
\cline { 2 - 8 } & Residual & 273.025 & 97 & 2.815 & & \\
\cline { 2 - 7 } & Total & 623.960 & 99 & & & \\
\hline
\end{tabular}

a. Dependent Variable: kepuasan

b. Predictors: (Constant), servicecape, servicequality

The results of the F test (sig. F) result is 62.340 with a probability value $(\mathrm{sig})=0.000 \mathrm{~F}$ count value $(62.340>\mathrm{F}$ table $(0.051)$ and the sig value is smaller than the probability value of 0.05 or $0.000<0.05$ then The hypothesis that service quality and servicescape has an effect on simultaneously (together) on customer satisfaction, accepted or proven.

Table 8. T Test Results

\begin{tabular}{|c|c|c|c|c|c|c|c|c|c|c|c|}
\hline \multicolumn{12}{|c|}{ Coefficients $^{\mathrm{a}}$} \\
\hline \multirow[b]{2}{*}{ Model } & & \multicolumn{2}{|c|}{$\begin{array}{c}\text { Unstandardized } \\
\text { Coefficients }\end{array}$} & \multirow{2}{*}{$\begin{array}{c}\begin{array}{c}\text { Standardized } \\
\text { Coefficients }\end{array} \\
\text { Beta }\end{array}$} & \multirow[b]{2}{*}{$t$} & \multirow[b]{2}{*}{ Sig. } & \multicolumn{3}{|c|}{ Correlations } & \multicolumn{2}{|c|}{ Collinearity Statistics } \\
\hline & & B & Std. Error & & & & Zero-order & Partial & Part & Tolerance & VIF \\
\hline 1 & (Constant) & .017 & 2.033 & & -.009 & 993 & & & & & \\
\hline & servicequality (X1) & .348 & .059 & .560 & 5.918 & .000 & .730 & .515 & .397 & .503 & 1.987 \\
\hline & servicecape $(X 2)$ & .133 & .052 & 241 & 2.548 & .012 & 636 & 250 & .171 & .503 & 1.987 \\
\hline
\end{tabular}

The results from the table above are explained as follows:

1. sig value 0.000 which means sig is smaller than the probability value of 0.05 or $0.000<0.05$ then $\mathrm{H} 1$ is accepted Ho rejected variable $\mathrm{X} 1$ has $\mathrm{t}$ count which is 5.918 with $\mathrm{t}$ table $=1.66 \mathrm{t}$ count $>\mathrm{t}$ table, it can be concluded that the variable $\mathrm{X} 1$ has a contribution to $\mathrm{Y}$. Positive values indicate that the variable $\mathrm{X} 1$ has a relationship with $\mathrm{Y}$, this means that the hypothesis that service quality has a significant influence on customer satisfaction, accepted or proven.

2. Value sig 0.012 which means sig is smaller than the probability value of 0.05 or $0.012<0.05$ then $\mathrm{H} 1$ is accepted Ho rejected variable $\mathrm{X} 2$ has t count which is 2.548 with $\mathrm{t}$ table $=1.66 \mathrm{t}$ count $>\mathrm{t}$ table it can be concluded that the variable $\mathrm{X} 2$ has a contribution to $\mathrm{Y}$. Positive values indicate that the variable X2 has a relationship with $\mathrm{Y}$, this means that the hypothesis that servicescape has a significant influence on customer satisfaction, accepted or proven.

\section{E. Discussion}

\section{Effect of Service Quality (X1) on Customer Satisfaction (Y)}

The results of hypothesis testing and regression analysis show that the Service Quality variable has a significant influence on Starbucks Coffee Customer Satisfaction, Jakarta, and the effect is positive. This can be seen from the probability value of $\mathrm{X} 1$ against $\mathrm{Y}$ is $<0.05$ ( $\mathrm{P}$ or Sig. $=0,000)$. Thing 
this means that there is a significant relationship of Service Quality (X1) to Consumer Satisfaction $(\mathrm{Y})$.

The results of the regression analysis of the effect of Service Quality on Consumer Satisfaction are 0.348, which means that every +1 increase of Service Quality will increase Consumer Satisfaction by 0.348 or $3.48 \%$.

\section{Effects of Servicescape (X2) on Customer Satisfaction (Y)}

The results of hypothesis testing and regression analysis show that the Servicescape variable has a significant influence on Starbucks Coffee Customer Satisfaction, Jakarta, and the effect is positive. This can be seen from the probability value of $\mathrm{X} 2$ towards $\mathrm{Y}$ is $<0.05$ ( $\mathrm{P}$ or Sig. $=0.012$ ).

This means that there is a significant relationship from Servicescape (X2) to Consumer Satisfaction $(\mathrm{Y})$.

The results of the regression analysis of the influence of Servicescape on Consumer Satisfaction amounted to 0.133 , which means that every +1 increase from Servicescape will increase Consumer Satisfaction by 0.268 or $26.8 \%$.

\section{Effect of Service Quality (X1) and Servicescape (X2) on Customer Satisfaction (Y)}

The results of hypothesis testing and regression analysis show that service quality, as well as servicescape variables have a joint and significant influence on Starbucks Coffee Customer Satisfaction, Jakarta and the effect is positive. This can be seen from the probability value of the $\mathrm{F}$ test for $\mathrm{Y}$ is $<0.05$ (Sig. $\mathrm{F}=$ $0,000)$. This means that there is a significant relationship together from service quality, and servicescape together towards Consumer Satisfaction $(\mathrm{Y})$. The F test results of the influence of the independent variables in this study on Consumer Satisfaction are 62.340, with the value of DF $=\mathrm{n}-1-\mathrm{k}=100-1-2=97$. The value of $\mathrm{R}$ is 0.750 , and the value of $\mathrm{R}$ Square (R2) is 0.562 . Both can predict the model, where in this study that the magnitude of the role or contribution of the variables in this research model, namely X1 or service quality, and X2 or servicescape is 0.750 or $75.0 \%$ for the $\mathrm{R}$ value, and 0.562 or $56.2 \%$ for the value R2. While the rest (for the value of R: $100 \%-75.0 \%=25 \%$; the value of R2: $100 \%-56.2 \%=43.8 \%$ ) that is equal to $25.0 \%$ for the value of $\mathrm{R}$, and $56.2 \%$ for the value of R2 , explained by other variables or other causes outside the research model.

These results indicate that this research model, namely service quality, and servicescape can be used as a model to predict customer satisfaction, especially customer satisfaction Starbucks Coffee, Jakarta, where the management of Starbucks Coffee, Jakarta can increase the level of customer satisfaction by increasing service quality, as well as servicescape. This will encourage an increase in Customer Satisfaction. 


\section{F. Conclusion and Suggestion}

\section{Conclusion}

1. Based on $t$ test testing it can be concluded that this study supports the proposed hypothesis that service quality has a significant effect on customer satisfaction of Starbucks Coffee, Jakarta.

2. The test results of the $t$ test state that the servicescape variable has a significant influence on customer satisfaction at Starbucks Coffee, Jakarta.

3. Based on the results of the F test it can be explained that the independent variables which consist of: service quality (X1), and servicescape (X2) simultaneously have an influence on customer satisfaction Starbucks Coffee, Jakarta $(\mathrm{Y})$. This is because $\mathrm{F}$ count $62.340>\mathrm{F}$ table.

\section{Suggestion}

Based on the conclusions above, a number of suggestions are expected to be useful for the company and other parties.

The suggestions given include:

1. The results of the study show that servicescape and service quality have a positive and significant effect on consumer satisfaction Starbucks Coffee, Jakarta because it has a probability value $(0,000)<0.05$, so Starbucks Coffee, Jakarta is expected to maintain and improve service quality and servicescape well.

2. Given that the independent variables in this study are very important in influencing customer satisfaction, it is expected that the results of this study can be used as a reference for future researchers to develop this research by considering other variables which are other variables outside the variables that have been entered in this research.

\section{REFERENCES}

Ghozali, Imam, 2016, Multi Variat Analysis Application with SPSS Program, Diponegoro University Publishing Agency: Semarang.

Kotler, P \& Keller, K. L. 2009. Marketing Management Analysis, Planning, Implementation, and Control. Salemba Empat, Jakarta Kotler, P \& Keller, K. L. 2016. Marketing management. Index, Jakarta

Lovelock, Christopher, Wirtz, Juchen, 2011. "Service Marketing: People, Technology, Strategy." Boston: Pearson.

Lovelock, Wirtz. 2011. Marketing Management. Index, Jakarta

Lumentut, Faris L., and Indrie D. Palandeng. "Facilities, Servicescape, and Service Quality, Its Impact on Consumer Satisfaction Mc Donald's Manado." Journal of Economic Research, Management, Business and Accounting, Vol 2.3 (2014). 
Manoppo Ferninda. "Service Quality and Servicescape Influence on Customer Satisfaction at Gran Puri Manado Hotel." Journal of Economic, Management, Business and Accounting Research Vol. 1 No.4 (2013).

Masloman, Mirna, Bode Lumanauw, and Irvan Trang. "Service Quality and Servicescape Influence on Consumer Satisfaction in Kentucky Fried Chicken Multimart Ranotana Manado" Journal of Economic Research, Management, Business and Accounting, Vol 2.4 (2015).

Putra, Aditya Nova., Saptarining Wulan, Rahmat Ingkadijaya. 2018. The Influence of Visualization of Food Appearance and Food Quality Towards Customer Satisfaction in Tutup Panci Bistro, Bumi Serpong Damai, South Tangerang. Tourism Research Journal. Vol. 2, No. 2: $105-$ 116.

Sugiyono, 2017. Statistics for Research. Alfabeta. Bandung.

Sugiyono. 2014. Qualitative Quantitative Research Methods and R \& D. Bandung: Alfabeta

Tjiptono, Fandy. 2014. Marketing Services. Yogyakarta: ANDI

Utami, Suryawardani. "The Effect of Servicescape on Customer Satisfaction, (Study on

Wijayaningratri Chatrin S, Budiyanto. "The Effect of Facilities, Location and Services on Customer Decisions at Mega Syariah Bank Walikukun". Journal of Management Science and Research, Vol 4.4 (2015).

Zeitaml, Valerie, Bitner, Mary \& Gremler, Dwayne, 2009. Service Marketing. New York: The McGraw Hill Companies. 